\title{
Cyanobacteria Dynamics in a Mediterranean Reservoir of the North East of Algeria: Vertical and Seasonal Variability
}

\author{
Hassen Touati ${ }^{*}$, Fatma Zohra Guellati', Salah Arif', Mourad Bensouilah' \\ 1 Ecobiology Laboratory for Marine Environments and Coastal Areas, Faculty of Sciences, BP 12 El-Hadjar, \\ University of Badji Mokhtar, 23000 Annaba, Algeria \\ * Corresponding author's e-mail: touati-hassen@hotmail.com
}

\begin{abstract}
Harmful cyanobacterial efflorescence is of growing global concern and its prediction and management require a better understanding of the growth control factors and dominance of cyanobacteria. The Zit-Emba reservoir located in the North-East of Algeria, was constructed to provide drinking water, irrigation, and fishing. The vertical and seasonal distribution variation of cyanobacteria community associated with environmental factors was comprehensively investigated from April 2016 to December 2016 at five depths, based on a seasonal sampling. The cyanobacteria communities of this reservoir are composed of seven genera belonging to five orders. The average proportion of Microcystis to total cyanobacteria population was 43\%, followed by Woronichinia $21 \%$, Planktothrix 16\%, Dolichospermum 13\%, Oscillatoria 5\%, and the remainder (Merismopedia, Spirulina) 2\%. The average cyanobacterial abundance was 2702 cells $/ \mathrm{mL}$, ranging from 360 to 65795 cells $/ \mathrm{mL}$ and this abundance exceeds the alert level 1 throughout the year. The most recurrent periods of increase took place from spring to summer and autumn. However, the vertical distributions of cyanobacteria displayed a similar profile each season, and abundances tended to decrease with depth. The results of the statistical analysis suggested that the most abundant of cyanobacterial genera were positively related to chlorophyll-a and water temperature and negatively with the concentrations of $\mathrm{NO}_{3}-\mathrm{N}, \mathrm{NH}_{4}-\mathrm{N}$, and $\mathrm{NO}_{2}-\mathrm{N}$. This demonstration of toxigenic cyanobacteria in this drinking water production dam involves regular monitoring of the cyanobacterial communities and cyanotoxins in raw water.
\end{abstract}

Keywords: Cyanobacteria community, Zit-Emba reservoir; environmental variables; dynamics; Algeria.

\section{INTRODUCTION}

In recent years, eutrophication has become the most important worldwide environmental issue regarding reservoirs and many other types of aquatic ecosystems [Sanchez-Carrillo et al., 2007]; severe eutrophication in freshwater reservoirs can cause the increasing appearance of harmful algal blooms, especially of cyanobacteria (Cyano-Habs) [Paerl, 2008; Codd, 2005]. However, cyanobacteria (commonly known as bluegreen algae) are an ancient group of prokaryotic organisms found in all terrestrial and aquatic ecosystems around the world [Whitton and Potts, 2000]. They are important primary producers and play a key role in the ecosystem functioning and biodiversity [Mur et al., 1999]. In addition, some species of cyanobacteria produce secondary me- tabolites that include hepatotoxic (microcystins), neurotoxic (anatoxins and saxitoxins) and cytotoxic (cylindrospermopsin) or dermatotoxic effects [Chorus, 2001]. These cyanotoxins have been associated with the decreased water quality and negative effects on higher trophic levels [Ferrão-Filho et al., 2009], as well as risks to human health (Paerl, 2008), and animal mortality and diseases [Jacoby and Kann, 2007; Nasri et al., 2008]. Moreover, several studies showed that different environmental factors influence the cyanobacterial bloom dynamics and toxin production. These include the abiotic factors such as temperature, pH, light availability, nutrients and hydrodynamics [Renaud et al., 2011; Elliott, 2012] but also the biotic interactions [Walsby et al., 2005; Ger et al., 2010]. Scientific research, preliminary studies and ongoing monitoring in many coun- 
tries provide a general overview of the extent of cyanobacteria and cyanotoxins [Chorus and Bartram, 1999; Chorus, 2001; Quiblier et al., 2008; Joung et al., 2011]. In Algeria, the climate change and water degradation provided ecological conditions for the development of cyanobacteria in many aquatic ecosystems. However, a monitoring of the environmental conditions and phytoplankton assemblages was carried out in several freshwater reservoirs and lakes from which problems of eutrophication and harmful algal blooms were reported [Nasri et al., 2008; Ouartsi et al., 2011; Djabourabi et al., 2014; Boussadia et al., 2015; Saoudi et al., 2015; Bidi-Akli et al., 2017; Saoudi et al., 2017; Guellati et al., 2017]. The Zit-Emba reservoir, located in the northeastern region of Algeria, was built to provide drinking water supplies and agricultural irrigation. In the last few years, parallel with the rapid development of the local economy and the intensive use of water resources, the water quality of this reservoir were significantly degraded due to untreated inputs of agricultural, industrial and domestic wastewater from the catchment area. The reservoir requires an effective biomonitoring program, but at present, there is no information on the diversity of phytoplankton and cyanobacteria in this water body.

This study aims, at a first step, to characterize the waters of the Zit-Emba reservoir by assaying the physicochemical parameters, to identify and count the cyanobacteria of this water body, and then to investigate the influence of some environmental parameters on the vertical and seasonal dynamics of cyanobacteria community through the application of statistical tests. These results will be used in evaluating the pollution level and developing a water monitoring program in the reservoir.

\section{MATERIALS AND METHODS}

\section{Study site}

The Zit-Emba reservoir $\left(36^{\circ} 41^{\prime} 00.68^{\prime \prime} \mathrm{N}\right.$, $\left.7^{\circ} 18^{\prime} 07.68^{\prime \prime} \mathrm{E}\right)$ is located in the North East of Algeria (Figure 1). This water body receives water from two rivers: El Hammam and El Mouguer; it has a surface area of $8.1 \mathrm{~km}^{2}$ with a capacity of 120 million $\mathrm{m}^{3}$ and a maximum depth of $41 \mathrm{~m}$ [Belhadj, 2007]. It was built to supply drinking water to the city of Skikda, and it is used for irrigation, fishing and nautical activities.

\section{Sampling procedure}

The sampling was conducted seasonally, in April, July, October and December 2016 at five depths $(0 \mathrm{~m}, 5 \mathrm{~m}, 10 \mathrm{~m}, 15 \mathrm{~m}$ and $20 \mathrm{~m})$ in the deepest zone of the dam (Figure 1). The water samples for the physicochemical analysis, chlorophyll-a (Chl-a) and cyanobacteria enumeration were collected with a Ruttner water sampler (1.000 ml, Hydrobios ${ }^{\circledR}$, Germany). The sampling water for the cyanobacterial identification was concentrated using a plankton net (20 $\mu \mathrm{m}$ mesh size, Hydro-Bios ${ }^{\circledR}$, Kiel, Germany) and the filtrate was immediately fixed with formaldehyde $4 \%$ final (v/v).

\section{Field measurement and water analysis methods}

The physical and chemical variables, including water temperature, $\mathrm{pH}$, dissolved oxygen, and conductivity were measured in situ using a multi-parameter probe (Multi 340i/SET-82362, WTW $®$, Germany). The water transparency was estimated with a Secchi disc (diameter $25 \mathrm{~cm}$ ). The water samples for nutrient determinations Nitrates $\left(\mathrm{NO}_{3}-\mathrm{N}\right)$, nitrites $\left(\mathrm{NO}_{2}-\mathrm{N}\right)$, ammonium $\left(\mathrm{NH}_{4}-\mathrm{N}\right)$ and orthophosphate $\left(\mathrm{PO}_{4}-\mathrm{P}\right)$ were analyzed using a spectrophotometer method according to the previous reports [ISO, 1994; Aminot and Chaussepied, 1983]. Suspended Solids (SS) concentrations were determined gravimetrically by filtering $200-400 \mathrm{ml}$ of water sample through combusted, pre-rinsed and pre-weighed glass microfiber filter of $0.45-\mu \mathrm{m}$ porosity (Whatman GF/CTM, GE Healthcare Ltd.) [Aminot and Chaussepied, 1983]. On the other hand, the water samples for chlorophyll-a determination were filtered through the same glass microfiber filters. Pigments were extracted in $90 \%$ aqueous acetone and measured by spectrophotometry (Shimadzu UV-1700 Pharma Spec UV-VIS) [Parsons, 1966]. The resulted water filtrates from Chl-a and SS samples filtration were kept in polypropylene sampling containers at $4^{\circ} \mathrm{C}$ in darkness until nutrient analysis and analyzed as soon as possible.

The identification of cyanobacteria is based on the observation of morpho-anatomical characteristics using a light microscope (Carl Zeiss, Axiostar plus 1169-149, Germany) and according to the following taxonomic literature [Komárek and Anagnostidis, 1999; Komárek and Anagnostidis, 2005; Komárek et al., 2014]. 


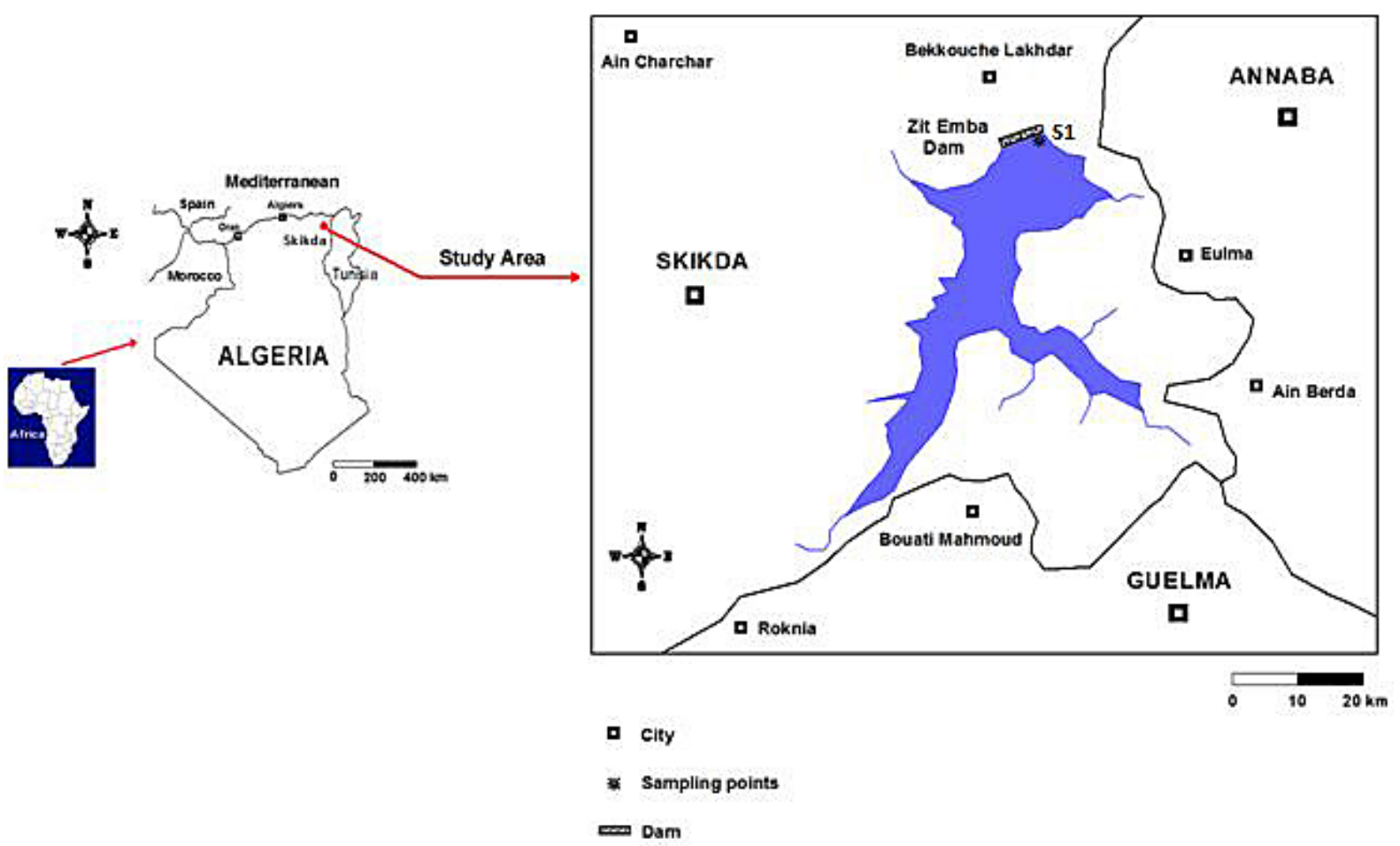

Fig. 1. Geographical position of the Zit-Emba reservoir and the location of the sampling station.

The enumeration of cells was carried out by a Nageotte cell and an optical microscope, as described in [Brient et al., 2008].

\section{Statistical analysis}

The statistical analyses were performed under $\mathrm{R}$ software (3.1.2). First of all, the normality condition of the sample distributions was checked before by applying the Shapiro-Wilk test. Then, the inter-seasons and inter-depths comparisons were performed using the non-parametric KruskalWallis test. In addition, the principal component analysis (PCA) was carried out using the R package FactoMineR. Finally, the correlations in our set of data were evaluated by the non-parametric Spearman correlation coefficient to analyze the intensity of relations between variables.

\section{RESULTS}

\section{Physical and chemical variables}

The means and ranges of environmental parameters at five depths are summarized in Table 1. The stratification events appeared in spring and lasted until autumn, whereas the water column was well-mixed in winter. During the stratification period, three different layers were clearly identi- fied in the Zit-Emba reservoir: epilimnion (water depth from 0 to $5 \mathrm{~m}$ ), metalimnion $(5-15 \mathrm{~m}$ ) and hypolimnion (from $15 \mathrm{~m}$ to the bottom). The water temperature showed a seasonal variation, the highest values being observed in summer at the surface and the lowest values in winter at the surface layer and also in the lower layer (Figure 2a). The dissolved oxygen concentrations decreased with depth in spring and summer, although the difference was more pronounced in summer (Figure $2 b$ ). The $\mathrm{pH}$ of water samples was alkaline (Figure 2c). The lowest values of conductivity were observed in spring and summer, with significant declines at the depth of $15 \mathrm{~m}$ (Figure 2d). Transparency oscillated in a small range, the lowest value was recorded in winter and the largest in spring (Table 1).

As far the nutrient concentrations (ammonium, nitrite, nitrate and orthophosphate) are concerned, they fluctuated with season and depth, but showing no clear trend. The highest concentrations of nitrate were found in the spring at $20 \mathrm{~m}$ depth, whereas the lowest concentrations were observed in summer at the surface (Figure 2e). The highest concentrations of nitrite appeared in winter at the depth of $20 \mathrm{~m}$, while the lowest concentrations were detected in summer at $5 \mathrm{~m}$ (Figure $2 \mathrm{f}$ ). The highest concentrations of ammonium were found in winter at the bottom waters, while the lowest concentrations were observed in the 
Table 1. Environmental variables recorded in the reservoir Zit-Emba from April 2016 to December 2016

\begin{tabular}{|c|c|c|c|c|c|}
\hline Parameters & Mean \pm sd & Min & Median & Max & C.V \\
\hline $\mathrm{WT}\left({ }^{\circ} \mathrm{C}\right)$ & 12.14 & 4.10 & 9.51 & 30.30 & 0.60 \\
\hline $\mathrm{pH}$ & 8.28 & 7.46 & 8.350 & 8.79 & 0.03 \\
\hline $\mathrm{DO}(\mathrm{mg} / \mathrm{L})$ & 8.37 & 2.91 & 8.40 & 10.64 & 0.26 \\
\hline Cond (Us/cm) & 647.10 & 568 & 654 & 702 & 0.04 \\
\hline Trans (cm) & 107.50 & 70 & 115 & 130 & 0.24 \\
\hline $\mathrm{SS}(\mathrm{mg} / \mathrm{L})$ & 21.18 & 8 & 20.05 & 44.70 & 0.44 \\
\hline $\mathrm{NH}_{4}-\mathrm{N}(\mathrm{mg} / \mathrm{L})$ & 0.33 & 0.24 & 0.300 & 0.49 & 0.24 \\
\hline $\mathrm{NO}_{2}-\mathrm{N}(\mathrm{mg} / \mathrm{L})$ & 0.06 & 0.04 & 0.060 & 0.08 & 0.14 \\
\hline $\mathrm{NO}_{3}-\mathrm{N}(\mathrm{mg} / \mathrm{L})$ & 4.95 & 3.89 & 4.670 & 7.82 & 0.17 \\
\hline $\mathrm{PO}_{4}-\mathrm{P}(\mathrm{mg} / \mathrm{L})$ & 0.22 & 0.09 & 0.180 & 0.55 & 0.61 \\
\hline $\mathrm{Chl}^{-a}(\mu \mathrm{gg} / \mathrm{L})$ & 7.09 & 1.06 & 4.58 & 31.24 & 0.95 \\
\hline
\end{tabular}

WT - water temperature, ${ }^{\circ} \mathrm{C}$; DO - dissolved oxygen, $\mathrm{mg} / \mathrm{L}$; Cond - Conductivity, $\mu \mathrm{S} / \mathrm{cm}$; Trans - transparency, cm; $\mathrm{NH}_{4}$ - Ammonium, mg/L; $\mathrm{NO}_{2}$ - Nitrite, mg/L; $\mathrm{NO}_{3}$ - Nitrate, (mg/L); $\mathrm{PO}_{4}$ - Orthophosphate, mg/L; SS suspended solids, mg/L; Chl-a - Chlorophyll a, ug/L; (Standard deviation - sd; coefficient of variation - C.V).

summer and the autumn at the surface (Figure $2 \mathrm{~g}$ ). The highest concentrations of orthophosphates were recorded in summer at the depth of $20 \mathrm{~m}$, while the lowest concentrations were reported in autumn at the surface (Figure $2 \mathrm{~h}$ ). The concentrations of suspended solids showed significant declines at $10 \mathrm{~m}$ depth during four seasons, while the highest values were recorded in winter and the lowest values in spring (Figure 2i). During the study period, the chlorophyll-a concentrations decreased steadily from the surface to bottom, with the lowest values recorded in winter at the depth of $20 \mathrm{~m}$ and the highest values in summer at the surface (Figure 2j).

The Kruskal-Wallis test detected significant differences among depths for Chl-a and SS. However, significant differences between seasons were found with regards to WT, DO, Cond, $\mathrm{NO}_{3}-\mathrm{N}$ and $\mathrm{PO}_{4}-\mathrm{P}(\mathrm{p}<0.05)$ (Table 2).

\section{Diversity of cyanobacteria community in the reservoir zit-emba}

A total of 5 orders, 7 families and 7 genera were determined from the water samples (Table 3 ). The proportion of the community composition was Microcystis 43\%, Woronichinia 21\%, Planktothrix 16\%, Dolichospermum 13\%, Oscillatoria $5 \%$, and the remainder (Merismopedia, Spirulina) $2 \%$. The estimation of the occurrence frequency shows that among the 7 identified genera, only Microcystis was ubiquitous. In addition, it can be observed the constancy of Woronichinia and the regularity of Planktothrix and Dolichospermum, respectively. On the other hand, the genus Oscillatoria had an accessory frequency and the 2 ot- ers genera belong to the incidental fraction of the cyanobacteria community (Table 4).

\section{Variation in cyanobacteria abundance}

The total cyanobacteria abundance in the ZitEmba reservoir (Figure 3) ranged from 360 in winter at a depth of $20 \mathrm{~m}$ to $65795 \mathrm{cells} / \mathrm{mL}$ in summer at the surface. The most recurrent periods of increase took place from spring to summer and autumn, while winter was the period of the lowest abundance. However, the vertical distributions of cyanobacteria displayed a similar profile in each season, and the abundances tended to decrease with depth. The Kruskal-Wallis test detected significant differences among depths, but no significant differences between seasons $(\mathrm{p}<0.05)$.

\section{SUCCESSION OF CYANOBACTERIA COMMUNITY}

The vertical and seasonal succession of cyanobacteria community in the Zit-Emba reservoir is shown in Figure 4.

In spring (Figure 4a), three genera of cyanobacteria were observed: Planktothrix, Microcystis and Woronichinia. In addition, this season was characterized by high densities of the Planktothrix genus throughout the water column compared to other genera recorded, with an average density of 3398 cells $/ \mathrm{mL}$.

In summer (Figure 4b), two genera Dolichospermum and Oscillatoria were added to those encountered in spring (Planktothrix, Microcystis and Woronichinia). The densities decreased with 
a)

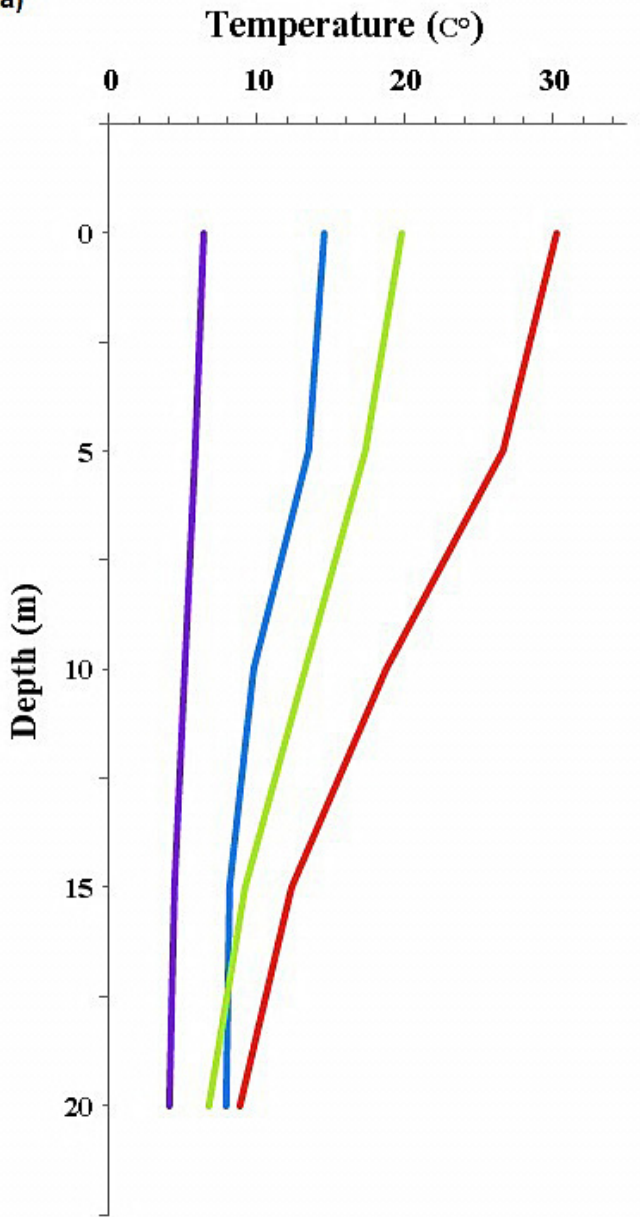

(c)

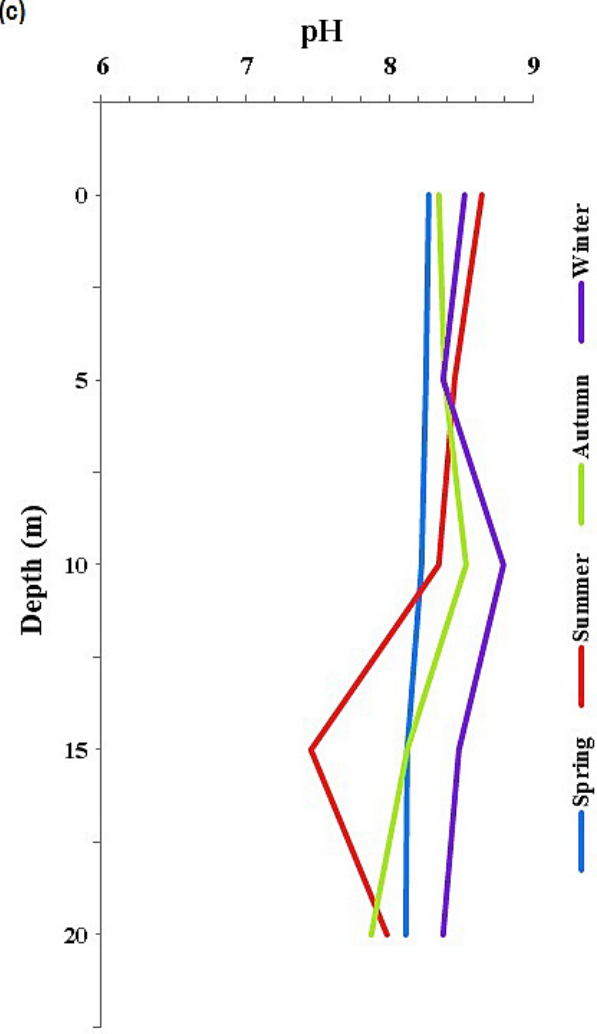

(b)

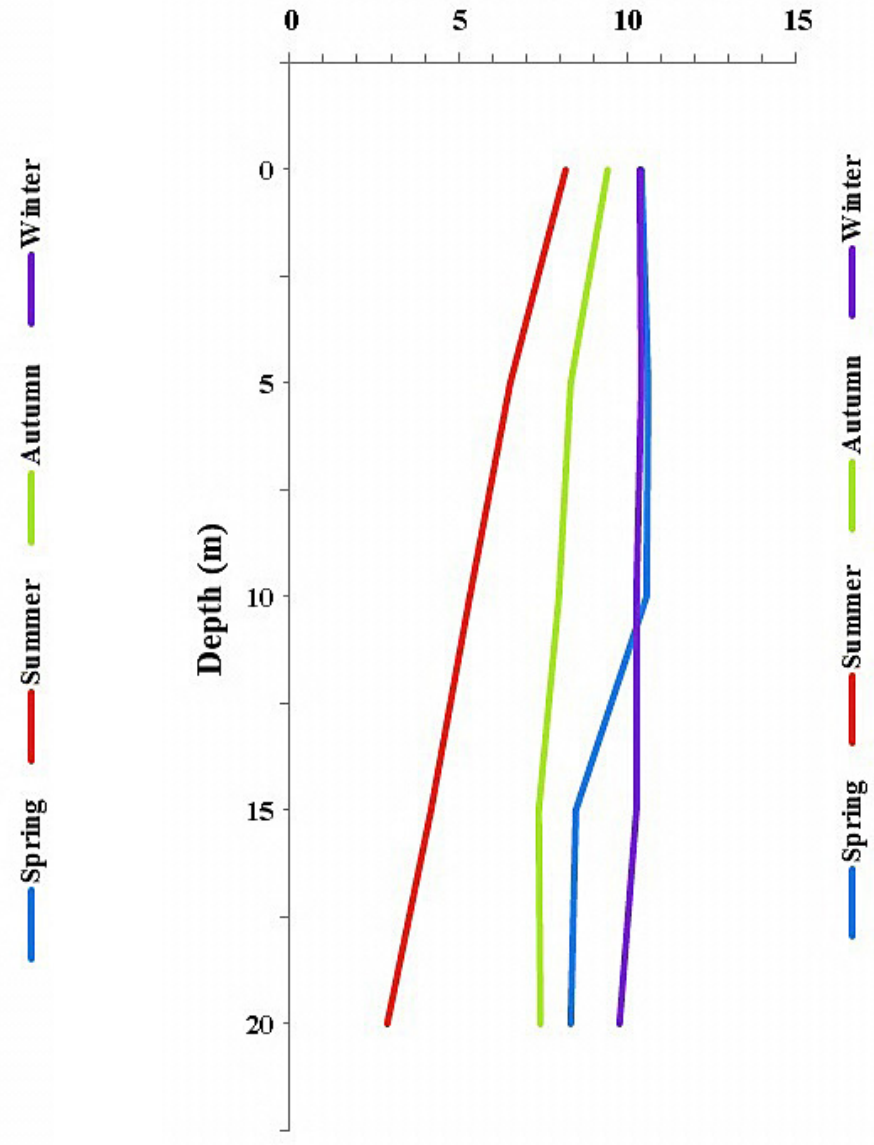

(d) Conductivity $(\mu \mathrm{S} / \mathrm{cm})$

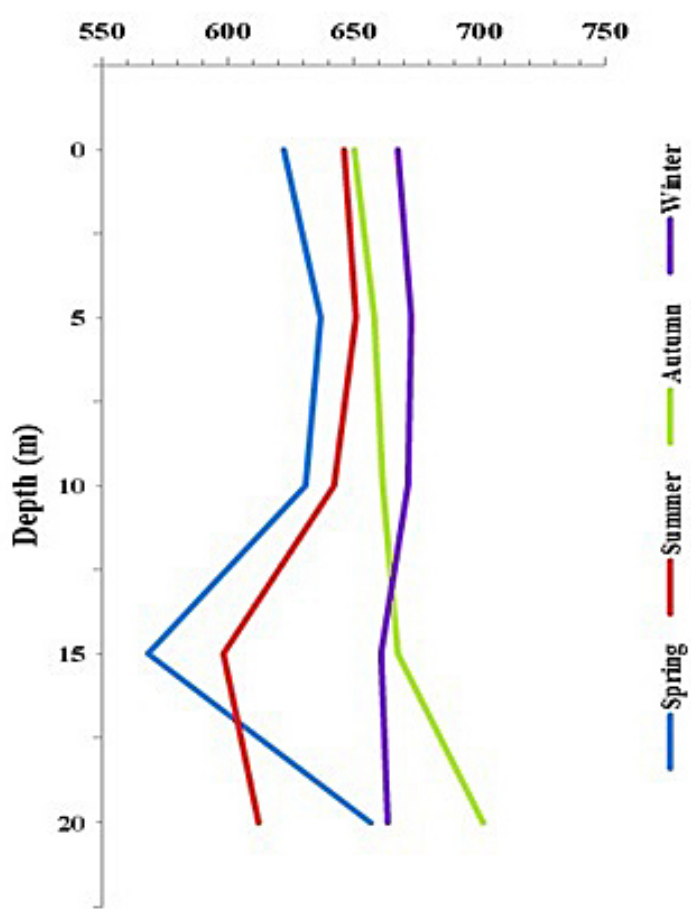

Fig. 2. Vertical and seasonal variations of environmental variables in Zit-Emba reservoir from April 2016 to December 2016: (a) water temperature;(b) dissolved oxygen; (c) pH; (d) conductivity 
(e)

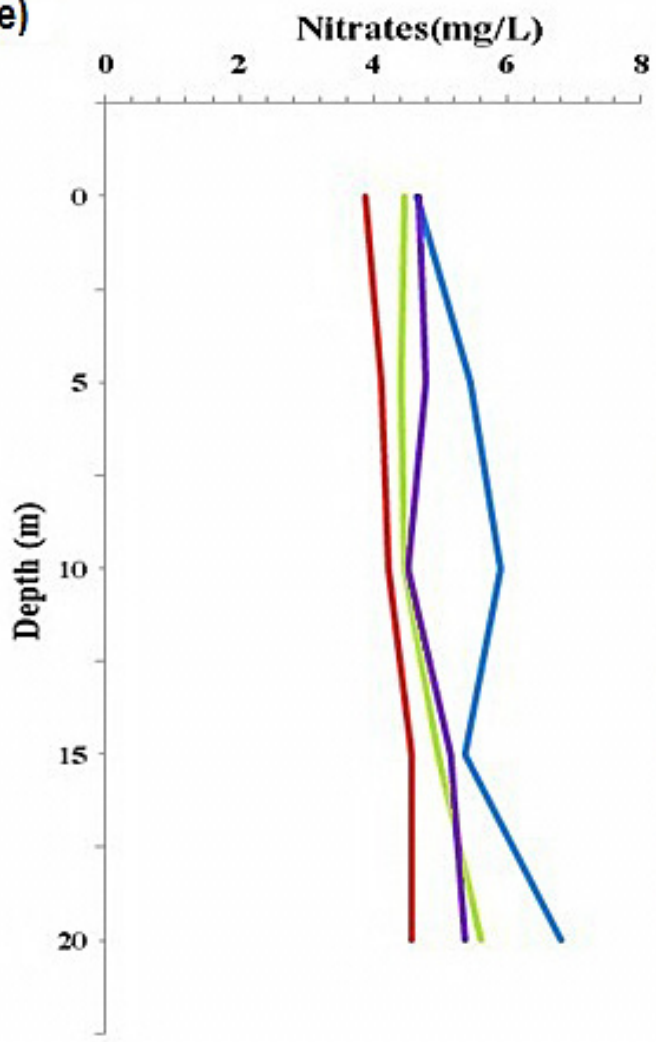

(g)

Ammonium(mg/L)

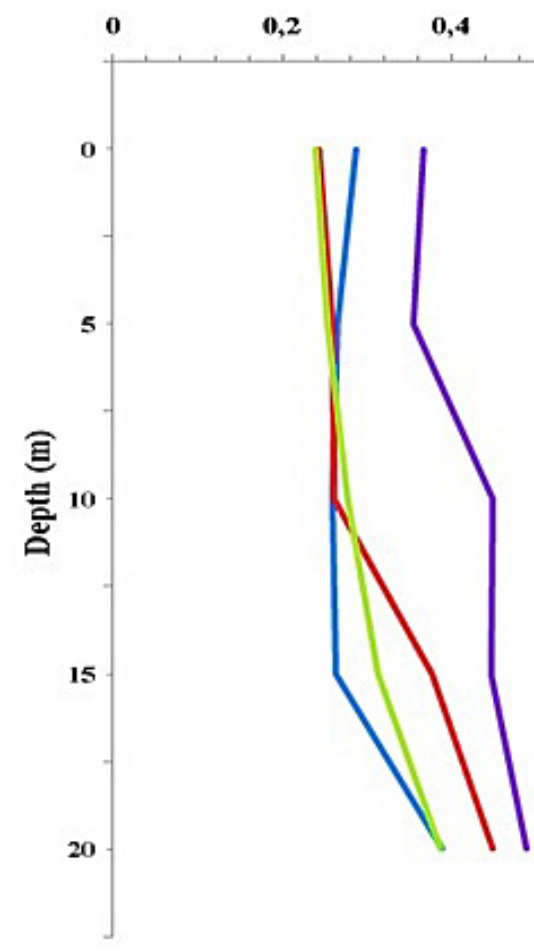

(f)

Nitrites(mg/L)

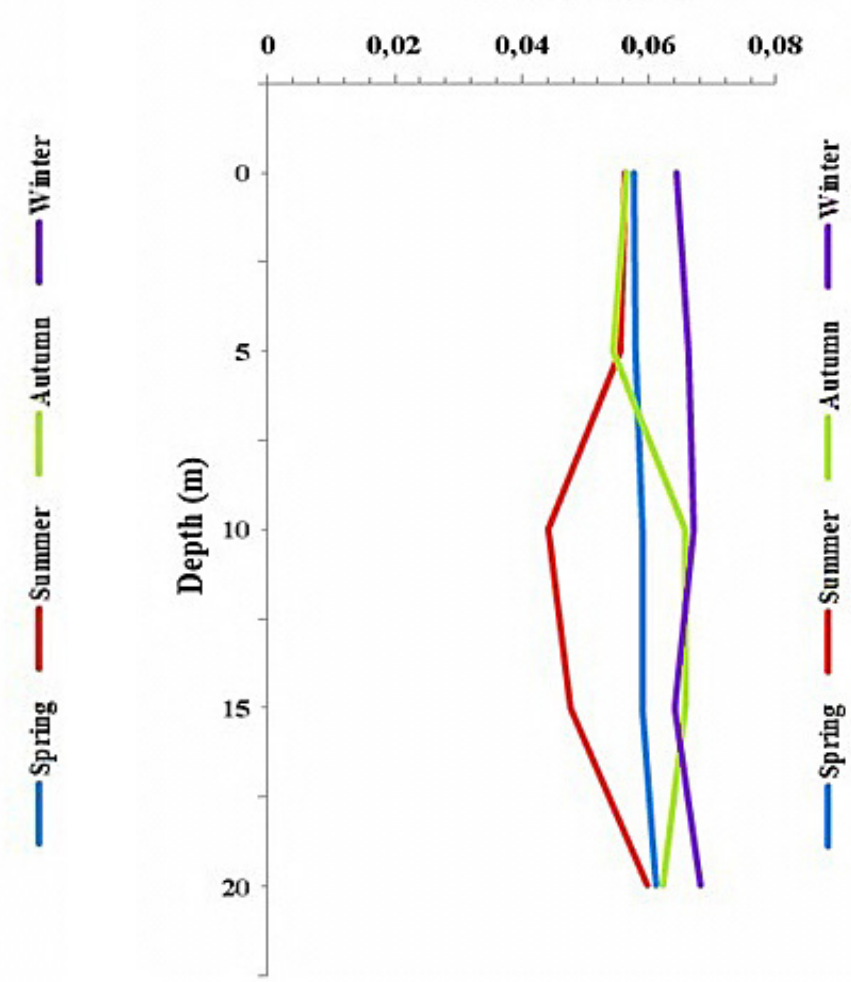

(h)

Orthophosphates(mg/L)

o

0,2

0,4

0,6

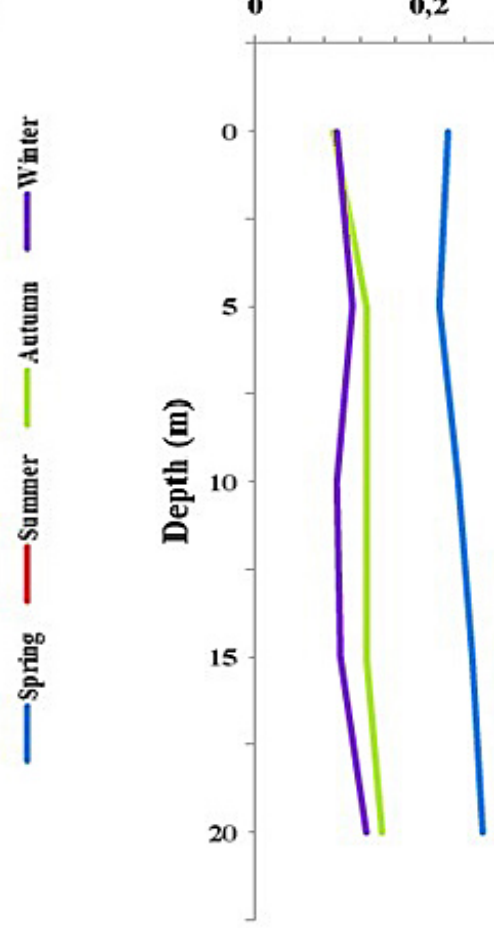

|

Fig. 2. Vertical and seasonal variations of environmental variables in Zit-Emba reservoir from April 2016 to December 2016: (e) Nitrates; (f) Nitrites; (g) Ammonium; (h) Orthophosphate 
(i)

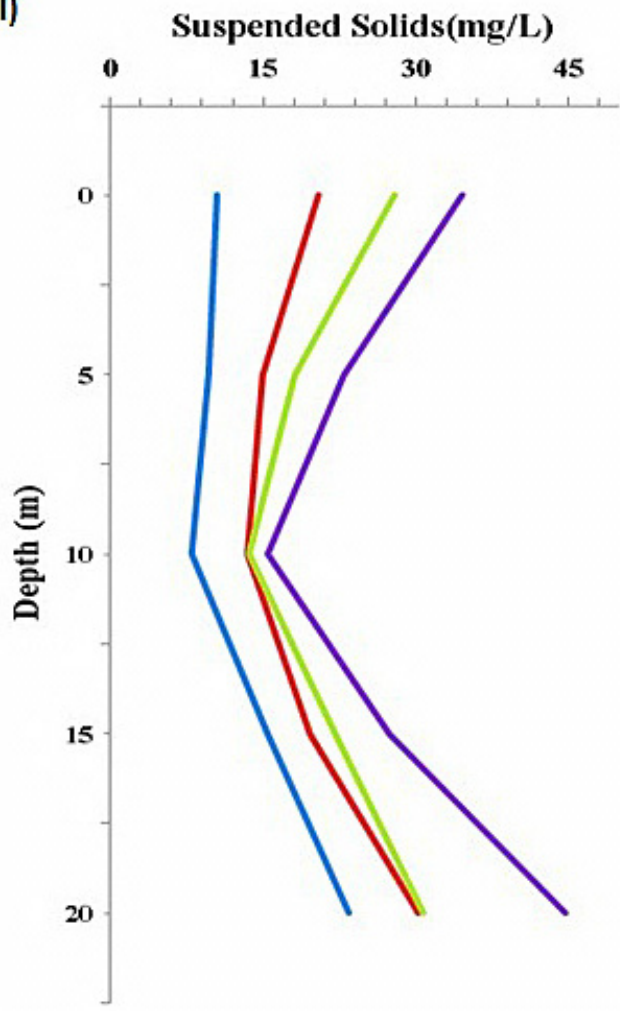

(i)

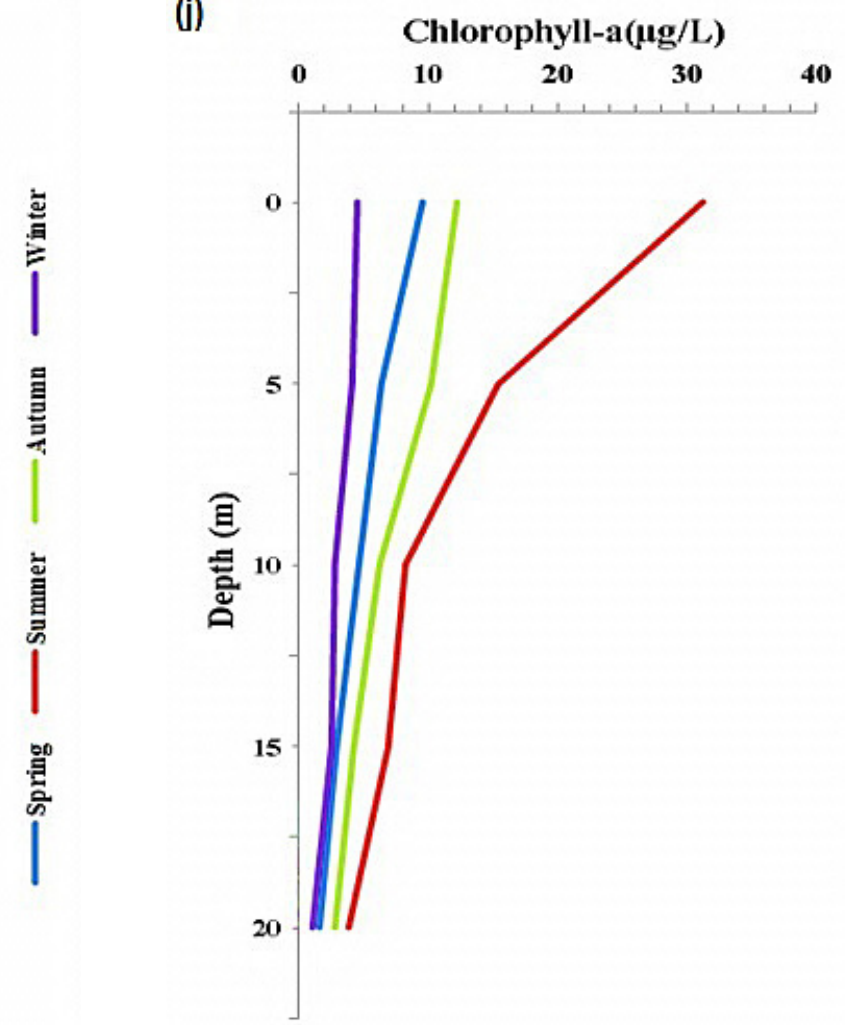

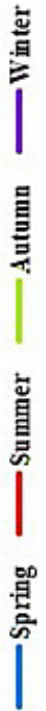

Fig. 2. Vertical and seasonal variations of environmental variables in Zit-Emba reservoir from April 2016 to December 2016: (i) Suspended Solids; (j) Chlorophyll-a.

Table 2. The inter-seasons and inter-depths comparison of median values of physico-chemical parameters and cyanobacteria density in the Zit-Emba reservoir

\begin{tabular}{|c|c|c|c|c|c|c|}
\hline \multirow{2}{*}{ Parameters } & \multicolumn{3}{|c|}{ Inter-depths } & \multicolumn{3}{c|}{ Inter-Saisons } \\
\cline { 2 - 7 } & $\mathrm{X}^{2}$ value & $\mathrm{p}$ - value & $\mathrm{df}$ & $\mathrm{X}^{2}$ value & $\mathrm{p}$ - value & $\mathrm{df}$ \\
\hline $\mathrm{WT}\left({ }^{\circ} \mathrm{C}\right)$ & 6.01 & 0.19 & 4 & 12.13 & 0,00 & 3 \\
\hline $\mathrm{pH}$ & 7.25 & 0.12 & 4 & 6.44 & 0.09 & 3 \\
\hline $\mathrm{DO}(\mathrm{mg} / \mathrm{L})$ & 3.40 & 0.49 & 4 & 14.01 & 0.00 & 3 \\
\hline Cond (Us/cm) & 1.34 & 0.85 & 4 & 13.48 & 0.00 & 3 \\
\hline Trans (cm) & 3,00 & 0,39 & 4 & $/ /$ & $/ /$ & $/ /$ \\
\hline $\mathrm{SS}(\mathrm{mg} / \mathrm{L})$ & 10.92 & 0.02 & 4 & 6.77 & 0.07 & 3 \\
\hline $\mathrm{NH}_{4}-\mathrm{N}(\mathrm{mg} / \mathrm{L})$ & 8.86 & 0.06 & 4 & 6.43 & 0.09 & 3 \\
\hline $\mathrm{NO}_{2}-\mathrm{N}(\mathrm{mg} / \mathrm{L})$ & 2.75 & 0.60 & 4 & 5.65 & 0.12 & 3 \\
\hline $\mathrm{NO}_{3}-\mathrm{N}(\mathrm{mg} / \mathrm{L})$ & 5.65 & 0.22 & 4 & 10.31 & 0.01 & 3 \\
\hline $\mathrm{PO}_{4}-\mathrm{P}(\mathrm{mg} / \mathrm{L})$ & 1.40 & 0.84 & 4 & 16.80 & 0.00 & 3 \\
\hline $\mathrm{Chl}^{-a}(\mu \mathrm{gg} / \mathrm{L})$ & 11.38 & 0.02 & 4 & 7.04 & 0.07 & 3 \\
\hline $\mathrm{DC}(\mathrm{cells} / \mathrm{mL})$ & 14.42 & 0.00 & 4 & 4.00 & 0.26 & 3 \\
\hline
\end{tabular}

$\chi^{2}$ - chi-squared value; $\mathrm{df}$ - degrees of freedom; $\mathrm{p}$-value - probability value; $(\mathrm{p}<0.05)$.

the increasing depth and only the genera Microcystis and planktothrix were present at the depth of $20 \mathrm{~m}$. However, Microcystis was the dominant genus, with an average density of 9663 cells $/ \mathrm{mL}$.

In autumn (Figure 4c), six cyanobacterial genera were recorded with the appearance of two genera Merismopedia and Spirulina, but at low densities and the absence of the planktothrix ge- nus for the first time, whereas at the surface and $5 \mathrm{~m}$ depth we noted the presence of all genera identified in this season, with the dominance of Microcystis and Woronichinia with mean densities of 6 778 cells/mL and 4036 cells/mL, respectively.

In winter (Figure 4d), we observed the same five genera found in summer, but with low densities. Microcystis and Woronichinia were domi- 
Table 3. List of Cyanobacteria Genera identified in Zit-Emba reservoir from April 2016 to December 2016

\begin{tabular}{|l|c|c|}
\hline \multicolumn{1}{|c|}{ Orders } & Family & Genera \\
\hline Chroococcales & Microcystaceae & Microcystis \\
\hline \multirow{2}{*}{ Synechococcales } & Coelosphaeriaceae & Woronichinia \\
\cline { 2 - 3 } & Merismopediaceae & Merismopedia \\
\hline \multirow{2}{*}{ Nostocales } & Aphanizomenonaceae & Dolichospermum \\
\hline \multirow{2}{*}{ Oscillatoriales } & Oscillatoriaceae & Oscillatoria \\
\cline { 2 - 3 } & Microcoleaceae & Planktothrix \\
\hline Spirulinales & Spirulinaceae & Spirulina \\
\hline
\end{tabular}

Table 4. The frequency of generic occurrence of the cyanobacterial community in the Zit-Emba reservoir from April 2016 to December 2016

\begin{tabular}{|l|c|c|}
\hline \multicolumn{1}{|c|}{ Genera } & $\begin{array}{c}\text { Frequency of } \\
\text { occurrence }(\mathrm{F} \%)\end{array}$ & Observation \\
\hline Microcystis & 100 & omnipresent \\
\hline Woronichinia & 75 & constant \\
\hline Planktothrix & 65 & regular \\
\hline Oscillatoria & 60 & regular \\
\hline Dolichospermum & 45 & accessory \\
\hline Merismopedia & 10 & incidental \\
\hline Spirulina & 10 & incidental \\
\hline
\end{tabular}

nant at the depth of $10 \mathrm{~m}$ and Planktothrix at 15 m; only Microcystis was present at $20 \mathrm{~m}$. However, the highest mean density in this season did not exceed 1000 cells/mL and was recorded by the genus Microcystis.

\section{Relation between abiotic and biotic variables}

The principal component analysis showed that the eigenvalues of the two first principal components represent up to $58.78 \%$ of the total variance (Figure 5).

The first axis accounted for $36.76 \%$ of the variation which was due to the positive loading of $\mathrm{NH}_{4}-\mathrm{N}(\mathrm{r}=0.71), \mathrm{NO}_{2}-\mathrm{N}(\mathrm{r}=0.69), \mathrm{NO}_{3}-\mathrm{N}$ $(\mathrm{r}=0.58)$ and SS $(\mathrm{r}=0.57)$ and negative loading of WT $(\mathrm{r}=-0.87), \mathrm{Chl}-a(\mathrm{r}=-0.75), \mathrm{PO}_{4}-\mathrm{P}$ $(\mathrm{r}=-0.65)$, Trans $(\mathrm{r}=-0.36)$, Mcs $(\mathrm{r}=-0.62)$, Doli $(\mathrm{r}=-0.61)$, Plank $(\mathrm{r}=-0.56)$, Worn $(\mathrm{r}=-0.55)$ and Osci $(\mathrm{r}=-0.40)$.

The second axis contributed for $22.02 \%$ of the variation found to be positively loaded by $\mathrm{pH}$ $(r=0.86)$, DO $(r=0.68)$ and Cond $(r=0.51)$.

Additionally, The PCA plot showed that the first principal component reflected the seasonal gradient and the mixing regime (Figure 5). On

\section{Cyanobacteria abundance (Cells/mL)}

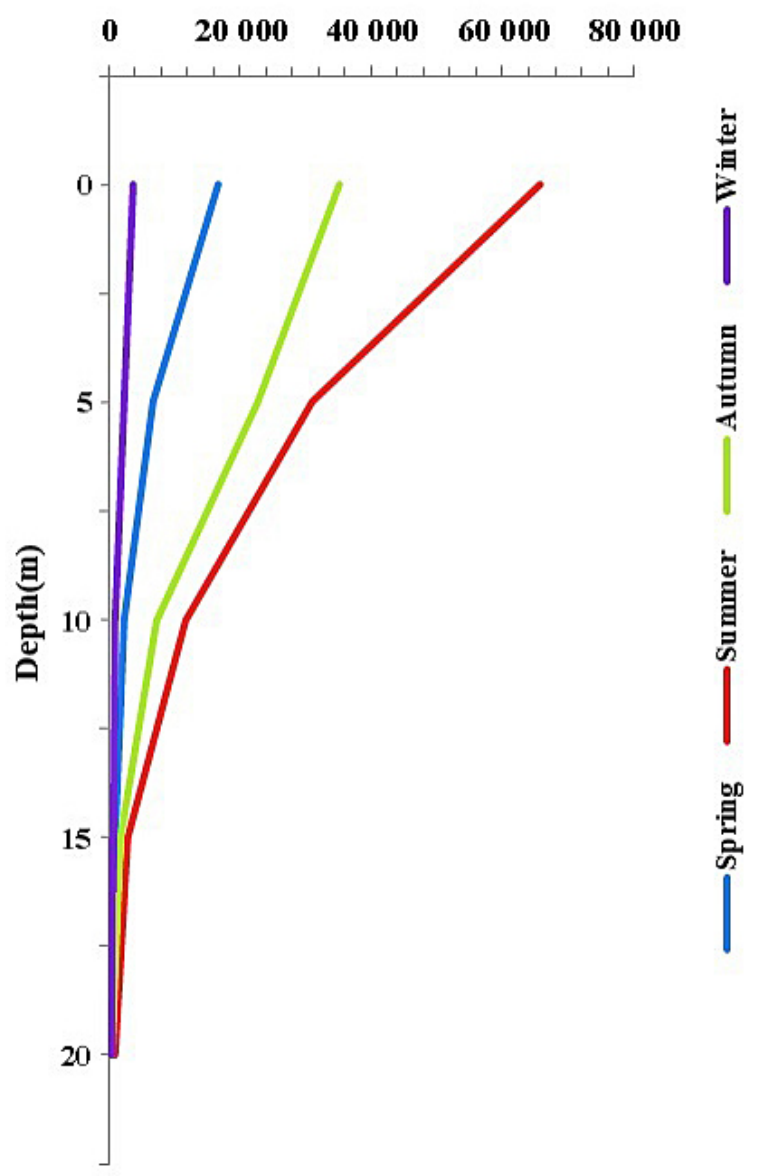

Fig. 3. Vertical and seasonal variation of the total Cyanobacteria abundance in Zit-Emba reservoir from April 2016 to December 2016.

the negative side of axis 1 , the sampling units of spring, summer and mid-autumn seasons correlated with the strong stratification and higher values of water temperature, chlorophyll-a and were also characterized by high abundances of cyanobacteria. On its positive side, the sampling units of winter correlated with mixing and, accordingly, higher dissolved nutrient concentrations and concentrations of suspended solids. However, this axis allowed us to reveal the separation between two different layers in the water epilimnion and metalimnion column (negative side of the axis), to the other layer hypolimnion (on the positive side of the axis).

The results of Spearman's rank correlation analysis between cyanobacterial genera and environmental variables are shown in Table 5.

In terms of the correlation coefficients, it is obvious that most abundance of cyanobacterial genera in the Zit-Emba reservoir was strongly re- 
(a)

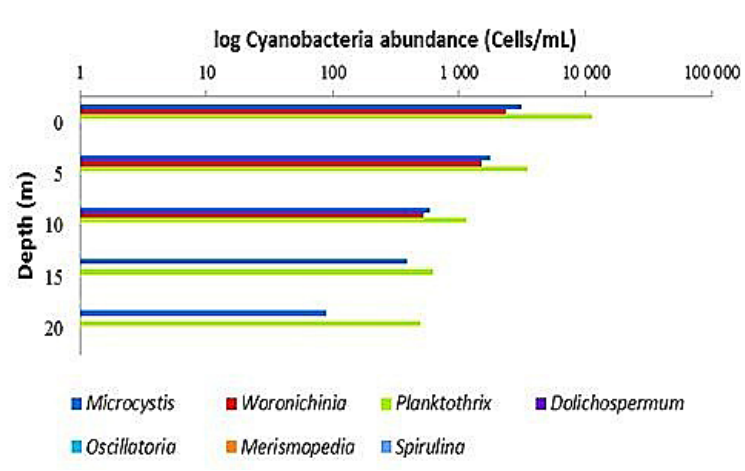

(c)

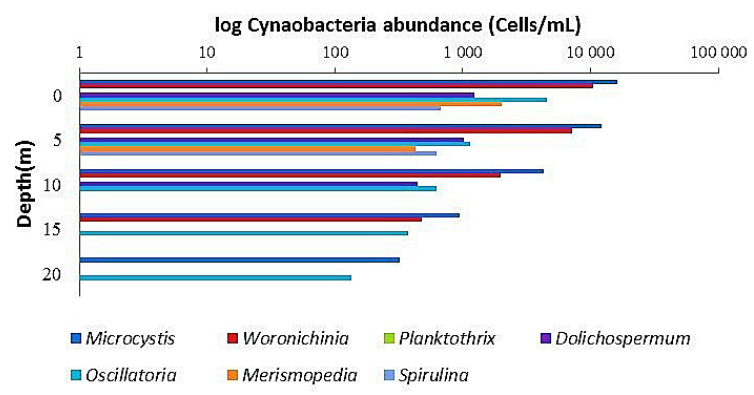

(b)

Summer

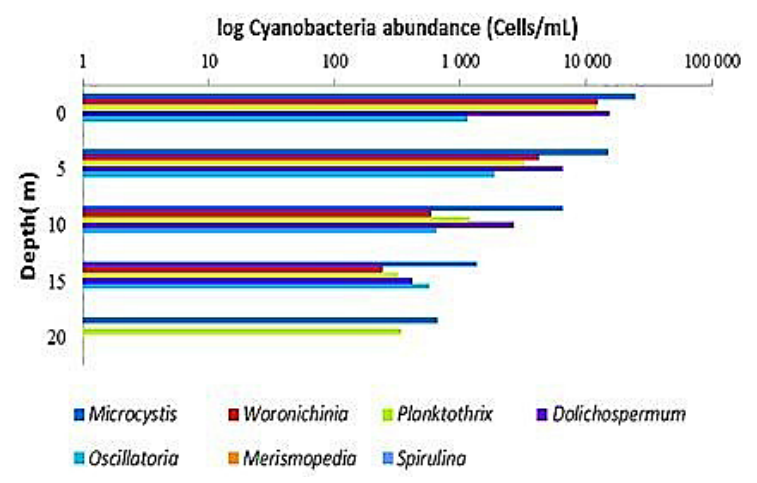

(d)

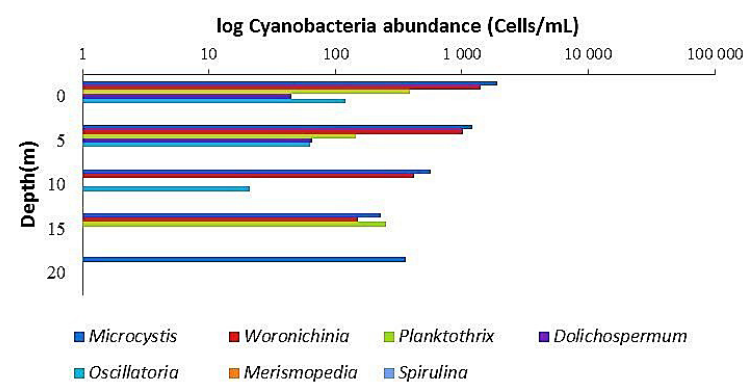

Fig. 4. Vertical and seasonal succession Cyanobacteria community in the Zit-Emba reservoir from April 2016 to December 2016. (a) in spring; (b) in summer; (c) in autumn; (d) in winter.
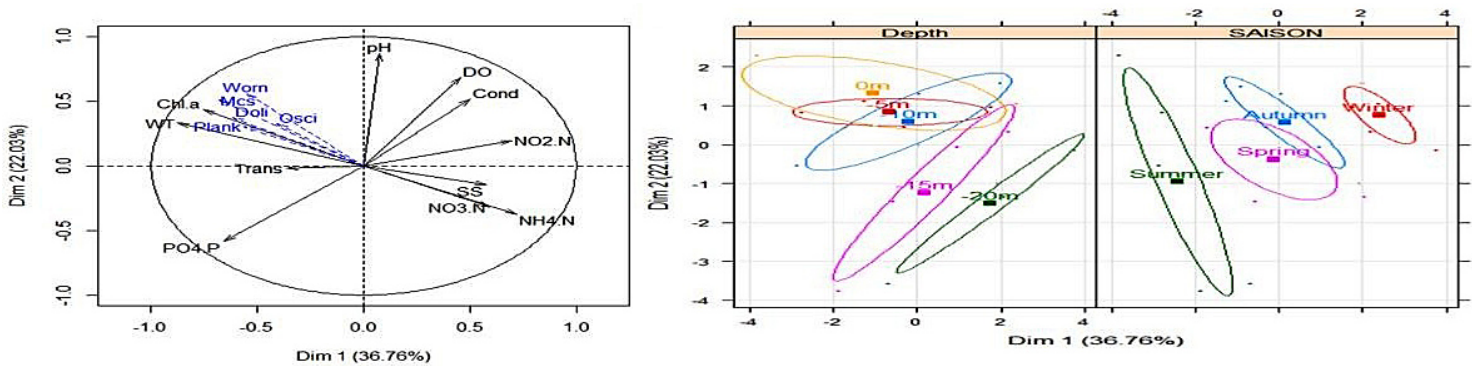

Fig. 5. Principal component analysis (PCA) based on biotic and abiotic variables during the period of April 2016 to December 2016 in the Zit-Emba reservoir at depths and seasonal sampling. Abbreviations for domains: WT - water temperature; $\mathrm{DO}$ - dissolved oxygen; $\mathrm{pH}$; Cond - conductivity; $\mathrm{NO}_{3}-\mathrm{N}$ - Nitrates; $\mathrm{NO}_{2}-\mathrm{N}$ - Nitrites; $\mathrm{NH}_{4}-\mathrm{N}$ - Ammonium; $\mathrm{PO}_{4}-\mathrm{P}$ - Orthophosphate; Chl- $a$ - Chlorophyll $a$; SS - Suspended Solids; Trans - Transparency; Mcs - Microcystis; Worn - Woronichinia; Plank - Planktothrix; Doli - Dolichospermum; Osci - Oscillatoria. Cell abundances as supplemental variables

lated to Chl- $a$ and WT which was in accordance with the PCA analysis. The abundance variation of Microcystis, Dolichospermum, Woronichinia and Oscillatoria were negatively correlated with $\mathrm{NO}_{3}-\mathrm{N}, \mathrm{NH}_{4}-\mathrm{N}$ and $\mathrm{NO}_{2}-\mathrm{N}$; Planktothrix has an abundance positively correlated with $\mathrm{PO}_{4}-\mathrm{P}$ and negatively correlated with Cond and SS. The Woronichinia abundance showed significant positive correlation with $\mathrm{pH}$. Besides, the variables Chl-a, WT, $\mathrm{NO}_{3}-\mathrm{N}, \mathrm{NH}_{4}-\mathrm{N}, \mathrm{NO}_{2}-\mathrm{N}$ and SS significantly correlated with each other.

\section{DISCUSSION}

The Zit-Emba reservoir is used by humans for several activities, including the recreational ones and the supply of drinking water, which makes the monitoring of cyanobacteria in such ecosystems of particular importance, especially as part of the assessment of the health risks linked to cyanobacterial blooms and their toxins [Codd et al., 2005].

The most important physical gradient in the Zit-Emba reservoir was the thermal-density 
Table 5. Spearman's rank correlation analysis between cyanobacterial genera and environmental variables

\begin{tabular}{|c|c|c|c|c|c|c|c|c|c|c|c|c|c|c|c|c|}
\hline & WT & $\mathrm{DO}$ & Chl.a & Cond & $\mathrm{pH}$ & Trans & SS & $\mathrm{NO}_{2}-\mathrm{N}$ & $\mathrm{NO}_{3}-\mathrm{N}$ & $\mathrm{PO}_{4}-\mathrm{P}$ & $\mathrm{NH}_{4}-\mathrm{N}$ & Mcs & Worn & Plank & Osci & Doli \\
\hline WT & 1.00 & & & & & & & & & & & & & & & \\
\hline DO & -0.28 & 1.00 & & & & & & & & & & & & & & \\
\hline Chl.a & $0.92^{\star \star \star}$ & -0.12 & 1.00 & & & & & & & & & & & & & \\
\hline Cond & $-0.49^{*}$ & 0.12 & -0.37 & 1.00 & & & & & & & & & & & & \\
\hline $\mathrm{pH}$ & 0.01 & 0.30 & 0.20 & 0.41 & 1.00 & & & & & & & & & & & \\
\hline Trans & 0.20 & 0.40 & 0.20 & -0.80 & -0.80 & 1.00 & & & & & & & & & & \\
\hline SS & $-0.51^{\star *}$ & -0.18 & $-0.47^{*}$ & $0.45^{*}$ & -0.04 & -0.80 & 1.00 & & & & & & & & & \\
\hline $\mathrm{NO}_{2}-\mathrm{N}$ & $-0.56^{\star *}$ & 0.15 & $-0.58^{\star *}$ & $0.58^{* *}$ & 0.22 & -0.77 & 0.33 & 1.00 & & & & & & & & \\
\hline $\mathrm{NO}_{3}-\mathrm{N}$ & $-0.62^{\star *}$ & $0.43^{*}$ & $-0.71^{\star \star *}$ & 0.08 & $-0.51^{* \star}$ & -0.20 & 0.17 & 0.33 & 1.00 & & & & & & & \\
\hline $\mathrm{PO}_{4}-\mathrm{P}$ & $0.44^{\star}$ & $-0.54^{\star \star}$ & 0.25 & $-0.69^{* \star *}$ & $-0.49^{*}$ & 0.21 & -0.28 & -0.39 & -0.11 & 1.00 & & & & & & \\
\hline $\mathrm{NH}_{4}-\mathrm{N}$ & $-0.83^{\star \star *}$ & -0.01 & $-0.81^{\star \star *}$ & 0.36 & -0.13 & -0.31 & $0.51^{*}$ & $0.43^{*}$ & $0.44^{*}$ & -0.16 & 1.00 & & & & & \\
\hline Mcs & $0.84^{* \star *}$ & -0.14 & $0.94^{* * *}$ & 0.94 & 0.37 & 0.20 & -0.32 & $-0.43^{*}$ & $-0.81^{\text {*** }}$ & 0.09 & $-0.75^{\star \star *}$ & 1.00 & & & & \\
\hline Worn & $0.74^{\star \star *}$ & 0.18 & $0.88^{* \star *}$ & -0.03 & $0.52^{\star \star}$ & 0.20 & -0.38 & -0.30 & $-0.65^{\star \star \star}$ & -0.14 & $-0.74^{\star \star \star}$ & $0.91^{\text {*** }}$ & 1.00 & & & \\
\hline Plank & $0.44^{\star}$ & 0.13 & 0.40 & $-0.62^{* *}$ & -0.04 & 0.00 & $-0.49^{*}$ & $-0.44^{*}$ & -0.05 & $0.61^{* *}$ & -0.36 & 0.26 & 0.24 & 1.00 & & \\
\hline Osci & $0.63^{*}$ & $-0.47^{*}$ & 0.69 & 0.17 & 0.29 & -0.20 & -0.00 & -0.24 & $-0.76^{\star \star \star}$ & -0.02 & $-0.57^{\star *}$ & $0.76^{\star \star \star}$ & $0.64^{* *}$ & -0.16 & 1.00 & \\
\hline Doli & $0.68^{\star \star \star}$ & -0.04 & $0.76^{\star \star \star}$ & -0.04 & 0.41 & -0.40 & -0.11 & -0.33 & $-0.82^{* \star *}$ & 0.13 & $-0.63^{\star *}$ & $0.84^{\star \star *}$ & $0.71^{\star \star \star}$ & 0.12 & $0.88^{\star \star \star}$ & 1.00 \\
\hline
\end{tabular}

WT - water temperature; DO - dissolved oxygen; Chl-a - Chlorophyll a; Cond - conductivity; $\mathrm{pH} ; \mathrm{NO}_{3}-\mathrm{N}-\mathrm{Ni}$ trates; $\mathrm{NO}_{2}-\mathrm{N}$ - Nitrites; $\mathrm{NH}_{4}-\mathrm{N}$ - Ammonium; $\mathrm{PO}_{4}-\mathrm{P}$ - Orthophosphate; Trans - Transparency; $\mathrm{SS}$ - Suspended Solids; Mcs - Microcystis; Worn - Woronichinia; Plank - Planktothrix; Doli - Dolichospermum; Osci - Oscillatoria, ${ }^{*} \mathrm{p} \leq 0.05 ; * * \mathrm{p} \leq 0.01 ; * * * \mathrm{p} \leq 0.001$.

stratification that was strongly coupled with the dissolved oxygen concentration gradient along the water column. Although the reservoir was completely oxic during the mixing period, an anoxic hypolimnion developed along the stratification. Accompanying with this gradient, we observe that the nutrients levels were greater in hypolimnetic waters than in epilimnetic ones, suggesting the presence of a vertical gradient in nutrient resources.

Higher ammonium concentrations on the bottom of this reservoir could result from ammonification of organic matter and dissimilatory nitrate reduction to ammonium, which is an important $\mathrm{N}$-cycling pathway, approved by anaerobic bacteria in aquatic ecosystems [Pajares et al., 2017].

The high content of orthophosphates in summer and in depth of the Zit Emba water column can be explained by the recycling of this element from sediment and dead matter; according to [Gachter and Muller, 2003], the process depends on the physical, chemical and biological mechanisms. The relatively high and irregular values of $\mathrm{pH}$ during the whole period of study might be due to the photosynthetic activity of phytoplankton. The fluctuations in the electrical conductivity may be due to changes in the rate of decomposition of organic matter or the influx of seeps and nutrients from the watershed. Furthermore, high levels of suspended solids found in this reservoir can result from a large variety of sources, such as sediment transported by storm water runoff, streambank and streambed erosion, decaying plant and animal matter, sewage, and industrial wastes.

The values of chlorophyll $a$ and transparency observed during the study period indicate that the water body fluctuated between a mesotrophic and eutrophic status, according to the OECD (Organization for Economic Co-operation and Development) classification scheme [Vollenweider and Kerekes, 1982].

The total cyanobacteria abundance in the ZitEmba reservoir, during the monitoring period, decreased along with depth; while the periods of increase occurred from spring to autumn. However, the chlorophyll-a concentration in the water column was highest in summer and decreased gradually in winter, similar to the abundance of the total cyanobacteria, which reached its maximum concentration during full stratification.

Referring to the guideline values admitted by WHO (cyanobacterial biomass $<2000$ cells/ ml), the seasonal variation of the total cyanobacteria population recorded in the reservoir Zit-Emba shows that the abundances exceed the alert level 1 [Affsa/Afsset, 2006] throughout the year.

In the Zit Emba water body, Microcystis, Woronichinia, Planktothrix and Dolichospermum represented more than $90 \%$ of the global density of the collected cyanobacteria. According to [Huber et al. 2012], long periods of stable stratification are competitively advantageous for 
gas-vacuolated cyanobacterial species (Microcystis, Woronichinia, Planktothrix and Dolichospermum); these genera are capable of making vertical movements by regulating their buoyancy in the water column through intracellular gas vacuoles. This mechanism gives this group the advantage of relocating to the optimum depth in a stable water column to obtain solar radiation in the surface water during the day and absorb enough nutrients in the lower layer at night [Walsby and Booker, 1980; Reynolds et al., 1987; Dokulil and Teubner, 2000]. These genera were reported to be the main CyanoHAB producers in the Mediterranean in the summer-autumn period [Carrasco et al., 2006]. In the Lake Alto Flumendosa of Sardinia, Planktothrix rubescens dominated between August 2011 and April 2012, alternating with Woronichinia naegeliana and Microcystis botrys; Dolichospermum planctonicum was always present at low densities [Stefanelli et al., 2017].

Nevertheless, the other genera, including oscillatoria, Merismopedia and Spirulina represent a small proportion of the total cyanobacterial community in the Zit-Emba reservoir. This low proportion was associated to the reconstitution of nutrients and the degradation of an effective light climate, but allowed the development of more competitive genera (Microcystis, Woronichinia, Planktothrix and Dolichospermum) in our water body [Paerl and Huisman, 2008].

Our results show that the most dominant genus of cyanobacteria was Microcystis; this genus is present throughout the water column and during the entire year. The dominance of this genus was also found in other Algerian reservoirs used for drinking water [Guellati et al., 2017; Nasri et al., 2007; Saoudi et al., 2015]. Microcystis blooms frequently occur in the ecosystems containing $\mathrm{N}_{2}$-fixing cyanobacteria belonging to the genera Aphanizomenon, Dolichospermumand Cylindrospermopsis [Wu et al., 2010; Soares et al., 2012]. Microcystis sp. is known to have a worldwide distribution [Harke et al., 2016] and to proliferate mainly in the eutrophic and hypereutrophic ecosystems during the summer season [Mariani et al., 2015; Van Wichelen et al., 2016].

In the Hammam Debagh reservoir, unlike what has commonly been found in numerous water bodies in temperate areas [Harke et al., 2016; Pobel et al., 2011; Mc Donald and Lehman, 2013], Microcystis was not associated with Dolichospermum and Aphanizomenon [Guellati et al., 2017]. According to [Guellati et al., 2017], these two genera were only found in a restricted number of samples, in which they have always displayed very low abundance in this water pond. In Mexa dam, [Saoudi et al., 2015] reported the constancy of Microcystis and the regularity of Oscillatoria but the presence of the genus Dolichospermum was not recorded in this water reservoir.

Woronichinia is a characteristic genus of cyanobacteria in standing-water ecosystems. According to [Wilk-Wozniak, 1996], this species was found as the accompanying species in water blooms caused by Microcystis aeruginosa. In our water body, Woronichinia was highly correlated with Microcystis; this genus was never dominant, but always present with an average proportion, $21 \%$ of the total cyanobacterial community. The strong presence of Woronichinia in summer and autumn is related to the water temperature.

Many studies reported that long-lasting stratification, with consequent high levels of nutrient enrichment of the hypolimnion, followed by mixing of the entire water column in late autumn, can significantly affect the cyanobacterial species composition, thus favoring Planktothrix blooms [Huber et al., 2012; Mariani et al., 2015]. This was the case for Zit Emba, which was subjected to a longer stratification period and the extensive growth of Planktothrix species from late autumn to spring during mixing. In the reservoir of Zit Emba, Planktothrix reaches $16 \%$ of the total cyanobacterial community; the maximum concentration of Planktothrix was observed in spring.

In Zit Emba, Dolichospermum showed a strong presence in summer and autumn; which was not surprising in the warmest season, as this genus prefers high summer temperatures and high water stability [Marchetto et al., 2009], with an extended distribution in areas with a temperate climate [Mariani et al., 2015; Padedda et al.,2017; Stefanelli et al., 2017].

In most studies, it was shown that interactive physical, chemical and biotic factors are involved in controlling the growth and dominance of bloom forming cyanobacteria [Aguilera et al., 2017; Paerl and Fulton, 2006; Thomas and Litchman, 2015; Guellati et al., 2017; Saoudi et al., 2015]. In the present study, the relationships between the environmental factors and Cyanobacteria communities were investigated by using Principal component analysis (PCA) and Spearman's rank correlation.

Our results indicated that the cyanobacterial genera in the Zit-Emba reservoir, including Microcystis, Woronichinia, Planktothrix, Dolichospermum and Oscillatoria were positively related 
to Chl-a and WT, which indicated the influence of thermal stratification on their growth [Dokulil and Teubner, 2000]. However, we noted negative correlations between most of the cyanobacteria genera and the concentrations of $\mathrm{NO}_{3}-\mathrm{N}, \mathrm{NH}_{4}-\mathrm{N}$ and $\mathrm{NO}_{2}-\mathrm{N}$, while a positive correlation should be observed in this case. This opposite pattern noticed in our study could be related to the high growth of the cyanobacteria communities that leads to the nutrient depletion [Abrantes et al., 2006].

Furthermore, it should be reported the positive correlation between the Planktothrix abundance and the PO4-P concentrations in this reservoir, revealing that high orthophosphates concentrations increase the growth rate of this genus. This corroborates the results found by previous studies of [Catherine et al., 2008 and Bidi-Akli et al., 2017]. The Woronichinia abundance showed a positive correlation with $\mathrm{pH}$; this may not be surprising, because later studies revealed the presence of this genus in meso-eutrophic and eutrophic reservoirs [Nowicka-Krawczyk and Żelazna-Wieczorek, 2017].

Demonstration of toxigenic cyanobacteria in this drinking water production dam involves regular monitoring of the cyanobacterial communities and cyanotoxins in raw water [Codd, 2000]. The monitoring of the water body can be performed using simple tools such as phycocyanin probes, to estimate the biomass of cyanobacteria [Brient et al., 2008; Macario et al., 2015] and ELISA kits [Lawton and Edwards, 2008; Triantis et al., 2010] used for the detection of different families of cyanotoxins (microcystins and others...).

The installation of a monitoring protocol of water bodies will not only improve the treatment of drinking water, but also allow making recommendations for fish consumption due to the cyanotoxins bioaccumulation in their flesh [Jia et al., 2014]. Nevertheless, it would be wise to encourage the authorities in charge of this sector as well as its inhabitants to implement the measures to reduce nutrient loads [Jeppesen et al., 2007] into the watershed through the establishment of a wastewater treatment plant before being discharged into the Wadi that supplies the dams.

\section{CONCLUSION}

The factors causing the dominance of one or other group are often difficult to reveal because several interacting factors are usually involved, which are not necessarily the same in different environments. Our study provided important evidence for the strong relationships among the trophic status, temperatures and cyanobacterial abundance. The phytoplankton responses to the nutrient variations cannot be separated from the responses to other, larger environmental changes occurring at the same time, such as global climate change. The progressive enlargement of the geographical distribution of harmful species, both in the Mediterranean area and globally, highlights the need for further detailed research on their ecology, toxicology, and genetics at the local scale.

\section{Acknowledgements}

We acknowledge the General Directorate for Scientific Research and Technological Development (DGRSDT) and the excellent assistance provided by the staff of the Zit-Emba National Agency of Dams and Transfers (ANBT).

\section{REFERENCES}

1. Abrantes N., Antunes S.C., Pereira M.J., Goncalves F. 2006. Seasonal succession of cladocerans and phytoplankton and their interactions in a shallow eutrophic lake (Lake Vela, Portugal). Acta Oecologia, 29, 54-64.

2. Afssa/Afsset. 2006. Évaluation des risques liés à la présence de cyanobactéries et de leurs toxines dans les eaux destinées à l'alimentation, à la baignade et autres activités récréatives. Rapport commun sur les risques sanitaires liés à la présence de cyanobactéries dans l'eau, p. 232. [In French]

3. Aminot A., and Chaussepied M. 1983. Manuel des analyses chimiques en milieu marin. Cnexo. Brest. [In French]

4. Belhadj M.Z. 2007. Etude de la pollution des eaux de surface du barrage de Zit El Emba. Région Est de Skikda. NE algérien. Mémoire de Magister, Dép Hydrau, Univ Batna. [In French]

5. Bidi-Akli S., Hacene H., Arab A. 2017. Impact of abiotic factors on the spatio-temporal distribution of cyanobacteria in the Zeralda's dam (Algeria).Revue d'Ecologie (la Terre et la Vie), 72(2), 159-167.

6. Boussadia M.I., Sehli N., Bousbia A., Ouzrout R., Bensouilah M. 2015. The effect of environmental factors on cyanobacteria abundance in Oubeira lake (Northeast Algeria). Research Journal of Fisheries and Hydrobiology, 10(14), 157-168.

7. Brient L., Lengronne M., Bertrand E., Rolland D., Sipel A., Steinmann D., Baudin I., Legeas M., Le Rouzic B., Bormans M. 2008. A phycocyanin probe as a tool for monitoring cyanobacteria in 
freshwater bodies. Journal of Environmental Monitoring, 10, 248-255.

8. Carrasco D., Moreno E., Sanchis D., Wörmer L., Paniagua T., Del Cueto A., Quesada A. 2006. Cyanobacterial abundance and microcystin occurrence in Mediterranean water reservoirs in Central Spain: microcystins in the Madrid area. Eur. J. Phycol, 41, 281-291.

9. Chorus I. 2001. Cyanotoxins: Occurrence, Causes, Consequences. Springer-Verlag KG, Berlin.

10. Chorus I., and Bartram J. 1999. Toxic cyanobacteria in water: a guide to their public health consequences, monitoring and management. Geneva: World Health Organization $416 \mathrm{p}$.

11. Codd G.A., Morrison L.F., Metcalf J.S. 2005. Cyanobacterial toxins: risk management for health protection.Toxicology and Applied Pharmacology, 203,264-272.

12. Djabourabi A., Touati H., Sehili N., Boussadia M. I., Bensouilah M. 2017. Study of the physicochemical parameters of water and phytoplankton in Lake Tonga (wetland of the national park of El Kala, North East of Algeria), International Journal of Biosciences, 11(3), 213-226.

13. Djabourabi A., Sehili N., Boussadia M., Samar F., Bensouilah M. 2014. Fluctuations des Paramètres Physico Chimiques et des Communautés Phytoplanctoniques dans le lac Oubeira (Nord-Est Algérien). European Journal of Scientific Research, 118(2), 183-196. [In French]

14. Dokulil M.T., and Teubner K. 2000. Cyanobacterial dominance in lakes. Hydrobiologia, 4381-3, 1-12.

15. Elliott J.A. 2012. Predicting the impact of changing nutrient load and temperature on the phytoplankton of England's largest lake, Windermere. Freshwater Biol, 57, 400-413.

16. Ferrão-Filho A.S., Soares M.C.S., de Freitas Magalhães V., Azevedo S.M.F.O. 2009. Biomonitoring of cyanotoxins in two tropical reservoirs by cladoceran toxicity bioassays. Ecotoxicol. Environ. Saf, 72, 479-489, http://dx.doi.org/10.1016/j. ecoenv.2008.02.002.

17. Gachter R., and Muller B. 2003. Why the phosphorus retention of lakes does not necessarily depend on the oxygen supply to their sediment surface. Limnology and Oceanography, 48, 929-933.

18. Ger K.A., Teh S.J., Baxa D.V., Lesmeister S., Goldman, C.R. (2010). The effects of dietary Microcystis aeruginosa and microcystin on the copepods of the upper San Francisco Estuary. Freshwater Biology, 55(7), 1548-1559.

19. Guellati F.Z., Touati H., Tambosco K., Quiblier C., Humbert JF., Bensouilah M. 2017. Unusual cohabitation and competition between Planktothrix rubescens and Microcystissp. (cyanobacteria) in a subtropical reservoir (Hammam Debagh) located in Algeria. PloS one, 12(8), e0183540.

20. Harke M.J., Steffen M.M., Gobler C.J., Otten T.G., Wilhelm S.W., Wood S.A., Paerl H.W. 2016. A review of the global ecology, genomics, and biogeography of the toxic cyanobacterium, Microcystis spp. Harmful Algae, 54, 4-20.

21. Huber V., Wagner C., Gerten D., Adrian, R. 2012. To bloom or not to bloom: contrasting responses of cyanobacteria to recent heat waves explained by critical thresholds of abiotic drivers. Oecologia, 169,245-56.

22. ISO/TC 147 (International Organization for Standardization) .1994. Environment: water quality. Chemical methods ISO Standards Compendium, Volume 2. 1st edition.

23. Jacoby J.M., Kann J. 2007. The occurence and response to toxic cyanobacteria in the Pacific Northwest, North America. Lake Reservoir Management, 23(2), 123-143.

24. Jeppesen E., Søndergaard M., Meerhoff M., Lauridsen T. L., Jensen J. P. 2007. Shallow lake restoration by nutrient loading reduction-some recent findings and challenges ahead. In Shallow Lakes in a Changing World, Springer, Dordrecht, pp. 239-252.

25. Jia J., Luo W., Lu Y., Giesy J.P. 2014. Bioaccumulation of microcystins (MCs) in four fish species from Lake Taihu, China: assessment of risks to humans. Science of the Total Environment, 487, 224-232.

26. Joung S.H., Oh H.M., Ko S.R., Ahn C.Y. 2011. Correlations between environmental factors and toxic and non-toxic Microcystis dynamics during bloom in Daechung Reservoir, Korea. Harmful Algae, 10,188-193.

27. Komárek J., and Anagnostidis K. 1999. Cyanoprokaryota: Part 1: Chroococcales. SüBwasser flora von Mittelleuropa Freshwater Flora of Central Europe. Spektrum Akademischer Verlag Heidelberg, Germany.

28. Komárek J., and Anagnostidis K. 2005.Cyanoprokaryota: part 2: Oscillatoriales SüBwasserflora von Mittelleuropa freshwater flora of Central Europe. Spektrum Akademischer Verlag Heidelberg. Germany.

29. Komárek J., Kaštovský J., Mareš J., Johansen J.R. 2014. Taxonomic classification of cyanoprokaryotes (cyanobacterial genera) Taxonomic classification of cyanoprokaryotes (cyanobacterial genera) 2014, using a polyphasic approach. Preslia, 86, 295-33.

30. Macário I.P.E, Castro B.B., Nunes M.I.S., Antunes S.C., Pizarro C., Coelho C., Gonçalves F., De Figueiredo D.R. 2015. New insights towards the establishment of phycocyanin concentration thresholds considering species-specific variability 
of bloom-forming cyanobacteria. Hydrobiologia, 757(1), 155-165.

31. Marchetto A., Padedda B.M., Mariani M.A., Lugliè A., Sechi N. 2009. A numerical index for evaluating phytoplankton response to changes in nutrient levels in deep Mediterranean reservoirs. Journal of Limnology, 68(1), 106-121.

32. Mariani M.A., Padedda B.M., Kaštovský J., Buscarinu P., Sechi, N., Virdis T., \& Lugliè, A. 2015. Effects of trophic status on microcystin production and the dominance of cyanobacteria in the phytoplankton assemblage of Mediterranean reservoirs. Scientific reports, 5, 17964.

33. McDonald K.E., and Lehman J.T. 2013. Dynamics of Aphanizomenon and Microcystis (cyanobacteria) during experimental manipulation of an urban impoundment. Lake and reservoir management, 29(2), 103-115.

34. Mur L.R., Skulberg O.M., Utkilen H. 1999. Cyanobacteria in the environment. In Toxic cyanobacteria in water: A guide to their public health consequences, monitoring and management, eds. I. Chorus and J. Bartram, pp. 15-40. London: E \& FN Spon.

35. Nasri H., Bouchaïcha N., Harche M.K. 2007. A new morphospecies of Microcystis sp forming a bloom in the Cheffia dam (Algeria): seasonal variation of microcystin concentrations in raw water and their removal in a full scale treatment plant. Environmental Toxicology, 22(4), 347-356.

36. Nasri H., El Herry S., Bouaicha N. 2008. First reported case of turtle deaths during a toxic Microcystis spp. bloom in Lake Ubeira, Algeria. Ecotoxicology and Environmental Safety, 71(2), 535-544.

37. Nowicka-Krawczyk P., and Żelazna-Wieczorek J. 2017. Dynamics in cyanobacterial communities from a relatively stable environment in an urbanised area (ambient springs in Central Poland). Science of the Total Environment, 579, 420-429.

38. Ouartsi A., Saoudi A., Chekireb D. 2011. Etude des efflorescences toxiques à cyanobactéries dans le barrage de Mexa, Algérie. Revue de Microbiologie Industrielle Sanitaire et Environnementale, 5(1), 81-100. [In French]

39. Padedda B.M., Sechi N., Lai G.G., Mariani M.A., Pulina S., Sarria M., Satta C.T., Virdis T., Buscarinu P., Lugl A. 2017. Consequences of eutrophication in the management of water resources in Mediterranean reservoirs: A case study of Lake Cedrino (Sardinia, Italy). Global Ecology and Conservation, 12, 21-35.

40. Paerl H. 2008. Nutrient and other environmental controls of harmful cyanobacterial blooms along the freshwater-marine continuum. Cyanobacterial harmful algal blooms. State Sci. Res. Needs, 217-237.

41. Paerl H.W., and Huisman J. 2008. Climate. Blooms like it hot.Science, 320(5872), 57-58.

42. Paerl H.W., and Fulton R.S. 2006. III. Ecology of harmful cyanobacteria. In Ecology of Harmful Algae; Graneli, E., Turner, J., Eds., Springer, Berlin, Germany, pp. 95-109.

43. Pajares S., Merino-Ibarra M., Macek M., Alcocer J. 2017. Vertical and seasonal distribution of picoplankton and functional nitrogen genes in a high-altitude warm-monomictic tropical lake. Freshwater Biol, 00, 1-14. https://doi.org/10.1111/ fwb. 12935.

44. Parsons T. R. 1966. Determination of photosynthetic pigments in sea-water. A survey of methods. Monogr. Oceanogr. Method, 1, 21-31.

45. Pobel D., Robin, J., Humbert J.F. 2011. Influence of sampling strategies on the monitoring of cyanobacteria in shallow lakes: Lessons from a case study in France. Water research, 45(3), 1005-1014.

46. Quiblier C., Leboulanger C., Sané S., Dufour P. 2008. Phytoplankton growth control and risk of cyanobacterial blooms in the lower Senegal River delta region. Water research, 42(4-5), 1023-1034.

47. Renaud S.L.B., Pick F.R., Fortin N. 2011. Effect of light intensity on the relative dominance of toxigenic and nontoxigenic strains of Microcystis aeruginosa. Applied and environmental microbiology, AEM-05246.

48. Reynolds C.S., Oliver, R.L., Anthony E., Walsby. 1987. Cyanobacterial dominance: The role of buoyancy regulation in dynamic lake environments. New Zealand journal of marine and freshwater research, 21(3), 379-390.

49. Sánchez-Carrillo S., Alatorre L. C., Sánchez-Andrés R., Garatuza-Payán J. 2007. Eutrophication and sedimentation patterns in complete exploitation of water resources scenarios: an example from northwestern semi-arid Mexico. Environmental Monitoring and Assessment, 132, 377-393.

50. Saoudi A., Brient L., Boucetta S., Ouzrout R., Bormans M., Bensouilah M. 2017. Management of toxic cyanobacteria for drinking water production of Ain ZadaDam. Environnemental Monitoring and Assessment, 189(7),361.

51. Saoudi A., Barour C., Brient L., Ouzrout R., Bensouilah M. 2015. Environmental parameters and spatio-temporal dynamics of cyanobacteria in the reservoir of Mexa (Extreme North-East of Algeria).Advances in Environmental Biology, 9(11), 109-121.

52. Soares M.C.S., Marinho M.M., Azevedo S.M., Branco C.W., Huszar V.L. 2012. Eutrophication and retention time affecting spatial heterogeneity in a tropical reservoir. Limnologica-Ecology and Management of Inland Waters, 42(3), 197-203.

53. Stefanelli M., Scardala S., Cabras P.A., Orrù A., Vichi S., Testai E., Funari E., Manganelli M. 2017. 
Cyanobacterial dynamics and toxins concentrations in Lake Alto Flumendosa, Sardinia, Italy. Advances in Oceanography and Limnology, 8(1), DOI: 10.4081/aiol.2017.6352.

54. Thomas M.K. and Litchman E. 2016. Effects of temperature and nitrogen availability on the growth of invasive and native cyanobacteria. Hydrobiologia, January 2016, Volume 763, Issue 1, pp 357-369.

55. Van Wichelen J., Vanormelingen P., Codd, G.A., Vyverman W. 2016. The common bloom-forming cyanobacterium Microcystis is prone to a wide array of microbial antagonists. Harmful algae, 55, 97-111.

56. Vollenweider R.A. and Kerekes J. 1982. Eutrophication of Waters. Monitoring, Assessment and Control. OECD Cooperative Programme on Monitoring of Inland Waters (Eutrophication Control). Environment Directorate, OECD, Paris, 154 pp.

57. Walsby A. E., Booker M. J. 1980. Changes in buoyancy of a planktonic blue-green alga in response to light intensity. British Phycol. J, 15,311-319.

58. Walsby A., Schanz F., Schmid M. 2005. The Burgundy-blood phenomenon: a model of buoyancy change explains autumnal water blooms by Planktothrix rubescens in Lake Zurich. New Phytol, 169 (1), 109-122.

59. Whitton B.A., and Potts M. 2000. Introduction to the cyanobacteria. In: Whitton B.A and Potts M (eds) Ecology of cyanobacteria: their diversity in time and space. Kluwer Academic Publishers, Dordrecht, pp 1-11, 689 pp.

60. Wilk-Wozniak E. 1996. Changes in the biomass and structure of phytoplankton in the Dobczyce Reservoir [Southern Poland]. Acta Hydrobiologica, 3(38).

61. Wu W. J., Li G. B., Li D. H., Liu Y. D. 2010. Temperature may be the dominating factor on the alternant succession of Aphanizomenon flos-aquae and Microcystis aeruginosa in Dianchi Lake. Fresenius Environ Bull, 19(5), 846-853. 